\title{
2,3-Butanediol Metabolism in the Acetogen Acetobacterium woodii
}

\author{
Verena Hess, Olga Oyrik, Dragan Trifunović, Volker Müller \\ Department of Molecular Microbiology and Bioenergetics, Institute of Molecular Biosciences, Johann Wolfgang Goethe University Frankfurt/Main, Frankfurt, \\ Germany
}

\begin{abstract}
The acetogenic bacterium Acetobacterium woodii is able to reduce $\mathrm{CO}_{2}$ to acetate via the Wood-Ljungdahl pathway. Only recently we demonstrated that degradation of 1,2-propanediol by $A$. woodii was not dependent on acetogenesis, but that it is disproportionated to propanol and propionate. Here, we analyzed the metabolism of $A$. woodii on another diol, 2,3-butanediol. Experiments with growing and resting cells, metabolite analysis and enzymatic measurements revealed that 2,3-butanediol is oxidized in an $\mathrm{NAD}^{+}$-dependent manner to acetate via the intermediates acetoin, acetaldehyde, and acetyl coenzyme A. Ethanol was not detected as an end product, either in growing cultures or in cell suspensions. Apparently, all reducing equivalents originating from the oxidation of 2,3-butanediol were funneled into the Wood-Ljungdahl pathway to reduce $\mathrm{CO}_{2}$ to another acetate. Thus, the metabolism of 2,3-butanediol requires the Wood-Ljungdahl pathway.
\end{abstract}

$T^{1}$ he ability to use molecular hydrogen as reductant for the fixation of two molecules of $\mathrm{CO}_{2}$ to acetate is characteristic for the phylogenetically diverse group of acetogenic bacteria (1-3). The pathway involved, the Wood-Ljungdahl pathway (WLP), not only allows the bacteria to grow autotrophically but also provides energy for growth: electron transfer from molecular hydrogen to $\mathrm{CO}_{2}$ is coupled to the generation of an electrochemical ion gradient across the cytoplasmic membrane (4-7). In the acetogenic model organism Acetobacterium woodii, the coupling ion was shown to be $\mathrm{Na}^{+}(5,8)$ and the electrochemical $\mathrm{Na}^{+}$potential is established by a membrane-bound $\mathrm{Fd}^{2-}: \mathrm{NAD}^{+}$oxidoreductase, most likely encoded by the $r n f$ genes $(9,10)$. During autotrophic growth, reduced ferredoxin is provided by an electron bifurcating hydrogenase that transfers electrons from molecular hydrogen not only to $\mathrm{NAD}^{+}$but also, in equal amounts, to ferredoxin (11). The $\mathrm{Na}^{+}$gradient established by the $\mathrm{Rnf}$ complex is then used to drive phosphorylation of ADP by an $\mathrm{Na}^{+}$-dependent $\mathrm{F}_{1} \mathrm{~F}_{\mathrm{o}}$ ATP synthase $(5,12-14)$.

However, acetogenic bacteria are not restricted to molecular hydrogen as reductant for carbon dioxide. Electrons may also derive from sugars (hexoses, as well as pentoses), acids (e.g., pyruvate and lactate), methyl groups, or alcohols $(2,15-17)$. Thus, the products of these fermentations are the oxidation products of the electron donor as well as acetate derived from $\mathrm{CO}_{2}$ reduction. Acetogens are metabolically very diverse and can, for example, not only reduce $\mathrm{CO}_{2}$ but other electron acceptors such as phenylacrylates (15), fumarate (18-20), and nitrate (17, 21-23). Recently, we discovered another nonacetogenic metabolism carried out by the model acetogen $A$. woodii: 1,2-propanediol (1,2-PD) is dehydrated to propionaldehyde that is then disproportionated to propionate and propanol. This fermentation does not involve the WLP and ATP is synthesized by substrate level phosphorylation in the course of the propionate kinase reaction (24). Degradation of 1,2-PD involves the formation of bacterial microcompartments, and these compartments were also present when another diol, 2,3-butanediol (2,3-BD), was the growth substrate (24). Since 2,3-BD metabolism in acetogens had not been studied in much detail and to test whether nonacetogenic growth on diols is a general rule, we analyzed the fermentation of 2,3-BD by A. woodii.

\section{MATERIALS AND METHODS}

Growth conditions. A. woodii DSM 1030 was grown under anaerobic conditions at $30^{\circ} \mathrm{C}$ in complex medium that was prepared as described previously $(8,25) \cdot 2,3-\mathrm{BD}$, acetoin, or fructose at $20 \mathrm{mM}$ was used as a substrate. Growth was monitored by measuring the optical density at 600 $\mathrm{nm}\left(\mathrm{OD}_{600}\right)$.

Preparation of cell suspensions. A. woodii was grown as described in 5 liters of complex medium to an $\mathrm{OD}_{600}$ of 0.4 to 0.5 when 2,3-BD was the carbon source or to an $\mathrm{OD}_{600}$ of 1.0 to 1.2 when acetoin was the carbon source. The culture was centrifuged anaerobically at $11,500 \times g$ and $4^{\circ} \mathrm{C}$ for $10 \mathrm{~min}$. The cells were washed twice in imidazole buffer $(50 \mathrm{mM}$ imidazole, $20 \mathrm{mM} \mathrm{MgSO}_{4}, 20 \mathrm{mM} \mathrm{KCl}, 2 \mathrm{mM}$ dithioerythritol [DTE], 4 $\mu \mathrm{M}$ resazurin; $\mathrm{pH} 7.0$ ) and resuspended in 2 to $3 \mathrm{ml}$ of imidazole buffer. The protein concentration was determined as described previously (26). In order to investigate the conversion of 2,3-BD or acetoin to acetate, 100-ml serum flasks (Glasgerätebau Ochs GmbH, Bovenden-Lenglern, Germany) were filled with $10 \mathrm{ml}$ of imidazole buffer containing either 10 $\mathrm{mM} 2,3-\mathrm{BD}$ or $10 \mathrm{mM}$ acetoin. If indicated, $\mathrm{KHCO}_{3}$ and $\mathrm{NaCl}$ were added to a concentration of $20 \mathrm{mM}$ each. If applied, the ionophore ETH2120 was added to a concentration of $80 \mu \mathrm{M}$. If the buffer contained bicarbonate, the gas phase of the serum flasks was changed to $10^{5} \mathrm{~Pa}$ of $\mathrm{N}_{2}+\mathrm{CO}_{2}$ $(80: 20[\mathrm{vol} / \mathrm{vol}])$, if there was no bicarbonate present the gas phase was $100 \% \mathrm{~N}_{2}$. The vessels were preheated to a temperature of $30^{\circ} \mathrm{C}$ in a water bath. The reaction was started by addition of resting cells to a final concentration of $1 \mathrm{mg} / \mathrm{ml}$. Henceforth, $500-\mu l$ samples were taken at time points as indicated. Samples were centrifuged immediately at $18,000 \times g$ for $1 \mathrm{~min}$, and the supernatant was stored at $-20^{\circ} \mathrm{C}$.

Preparation of cell extract and membranes. A. woodii was grown as described in 5 liters of complex medium to an $\mathrm{OD}_{600}$ of 0.4 to 0.5 when 2,3-BD was the carbon source or to an $\mathrm{OD}_{600}$ of 1.0 to 1.2 when acetoin

Received 24 March 2015 Accepted 28 April 2015

Accepted manuscript posted online 1 May 2015

Citation Hess V, Oyrik O, Trifunović D, Müller V. 2015. 2,3-Butanediol metabolism

in the acetogen Acetobacterium woodii. Appl Environ Microbiol 81:4711-4719. doi:10.1128/AEM.00960-15.

Editor: S.-J. Liu

Address correspondence to Volker Müller, vmueller@bio.uni-frankfurt.de. V.H. and O.O. contributed equally to this article.

Copyright $\odot$ 2015, American Society for Microbiology. All Rights Reserved. doi:10.1128/AEM.00960-15 


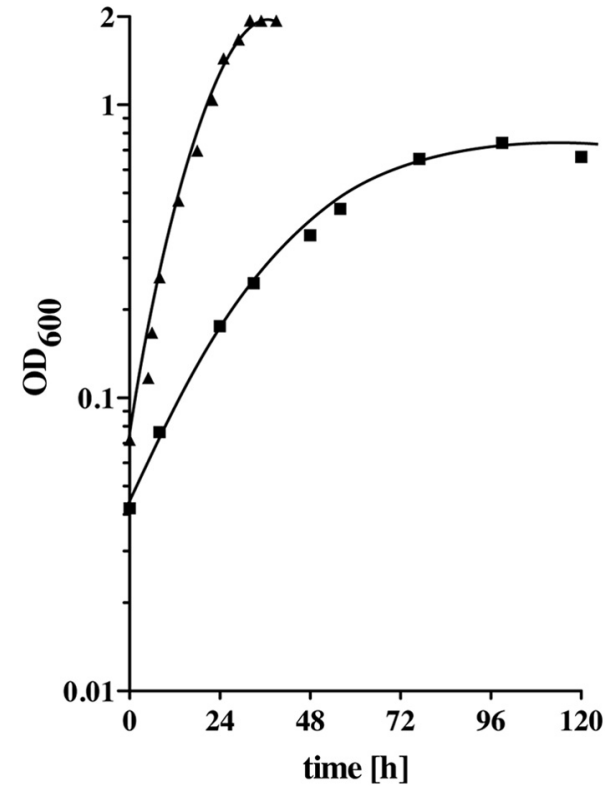

FIG 1 Growth of $A$. woodii on 2,3-BD and acetoin. A. woodii was grown on either $20 \mathrm{mM}$ 2,3-BD (ם) or $20 \mathrm{mM}$ acetoin $(\boldsymbol{\Delta})$ in phosphate-carbonatebuffered complex medium. The $\mathrm{OD}_{600}$ was determined. The curves shown are representative for three independent growth experiments.

was the carbon source. The culture was centrifuged anaerobically at $11,500 \times g$ and $4^{\circ} \mathrm{C}$ for $10 \mathrm{~min}$. Cells were washed twice in washing buffer (25 mM Tris, $420 \mathrm{mM}$ sucrose, $2 \mathrm{mM}$ DTE, $4 \mu \mathrm{M}$ resazurin; $\mathrm{pH}$ 7). Afterward, the cells were resuspended in $25 \mathrm{ml}$ of washing buffer containing $200 \mathrm{mg}$ of lysozyme and incubated at $37^{\circ} \mathrm{C}$ for $1 \mathrm{~h}$. After sedimentation of the cells at $11,500 \times \mathrm{g}$ and $4^{\circ} \mathrm{C}$ for $10 \mathrm{~min}$, the cells were resuspended in $15 \mathrm{ml}$ of storage buffer (50 mM KP, 2 mM DTE, $4 \mu \mathrm{M}$ resazurin; $\mathrm{pH}$ 7) and disrupted by two passages through a French press $(110 \mathrm{MPa})$. Cell debris and whole cells were removed by a centrifugation step for $30 \mathrm{~min}$ at $23,700 \times g$. The cell extract was stored at $4^{\circ} \mathrm{C}$. For preparation of membranes, the cell extract was centrifuged at $150,000 \times g$ at $4^{\circ} \mathrm{C}$ for $2 \mathrm{~h}$ and washed once in storage buffer. After the second centrifugation step, membranes were resuspended in 3 to $4 \mathrm{ml}$ of storage buffer.

Measurement of $\mathrm{NAD}^{+}$-dependent decrease of acetoin. Glass vessels $(10 \mathrm{ml})$ were filled with $6.3 \mathrm{ml}$ of assay buffer $(100 \mathrm{mM}$ Tris, $0.5 \mathrm{mM}$
$\mathrm{MgCl}_{2}, 2 \mathrm{mM}$ DTE, $4 \mu \mathrm{M}$ resazurin; $\mathrm{pH}$ 7.5), and cell extract was added to a concentration of $1 \mathrm{mg} / \mathrm{ml}$. Subsequently, acetoin, coenzyme A (CoA) and thiamine pyrophosphate (TPP) were added to concentrations of 8 $\mathrm{mM}, 100 \mu \mathrm{M}$, and $0.8 \mathrm{mM}$, respectively. The assay was started by the addition of $10 \mathrm{mM} \mathrm{NAD}^{+}$. Henceforth, $500-\mu l$ samples were taken at the indicated time points, and $50 \mu \mathrm{l}$ of trichloroacetic acid was added immediately. Samples were centrifuged at $18,000 \times g$ for $1 \mathrm{~min}$, and the supernatant was stored at $-20^{\circ} \mathrm{C}$.

Determination of acetate, ethanol, and acetoin. Remaining suspended particles were removed from the supernatant of all samples by a centrifugation step $(15,000 \times g ; 5 \mathrm{~min})$. A total of $400 \mu \mathrm{l}$ of the resulting supernatant was mixed with $500 \mu \mathrm{l}$ of $13.6 \mathrm{M}$ acetone and $50 \mu \mathrm{l}$ of $2 \mathrm{M}$ phosphoric acid. The samples were analyzed by gas chromatography on a Clarus 580 GC (Perkin-Elmer, Waltham, MA) with an ELITE-FFAP capillary column ( $30 \mathrm{~m}$ by $0.32 \mathrm{~mm}$; Perkin-Elmer) with the following temperature profile: $60^{\circ} \mathrm{C}$ for $3 \mathrm{~min}$, followed by a temperature gradient to $150^{\circ} \mathrm{C}$ with $10^{\circ} \mathrm{C} \mathrm{min}^{-1}$. Helium was used as the carrier gas with a flow rate of $40 \mathrm{~cm} \mathrm{~min}{ }^{-1}$. The sample volume was $0.5 \mu l$, injected with an autosampler (injection temperature of $250^{\circ} \mathrm{C}$, split of 1:50). Acetate, acetoin, and ethanol were analyzed with a flame ionization detector at $250^{\circ} \mathrm{C}$. The peak areas were proportional to the concentration of each substance and calibrated with standard curves. A total of $10 \mathrm{mM}$ 1-propanol was used as the internal standard in all cases.

Measurement of enzymatic activities. All enzyme assays were carried out at $30^{\circ} \mathrm{C}$ in glass cuvettes sealed with rubber stoppers containing a $100 \% \mathrm{~N}_{2}$ atmosphere.

2,3-BD:NAD ${ }^{+}$oxidoreductase activity was measured in $1 \mathrm{ml}$ of buffer containing $200 \mathrm{mM}$ glycine, $2 \mathrm{mM}$ DTE, $4 \mu \mathrm{M}$ resazurin ( $\mathrm{pH}$ 9), and 150 $\mu \mathrm{g}$ of cell-free extract. 2,3-BD was added to a concentration of $300 \mathrm{mM}$ and the reaction was started by addition of $1 \mathrm{mM} \mathrm{NAD}^{+}$. Formation of $\mathrm{NADH}$ was measured photometrically at $340 \mathrm{~nm}$.

Acetoin:NADH oxidoreductase activity was measured in $1 \mathrm{ml}$ of buffer containing $200 \mathrm{mM}$ glycine, $2 \mathrm{mM}$ DTE, $4 \mu \mathrm{M}$ resazurin ( $\mathrm{pH}$ 9), and $150 \mu \mathrm{g}$ of cell extract. Acetoin was added to a concentration of $10 \mathrm{mM}$, and the reaction was started by addition of $300 \mu \mathrm{M}$ NADH. Oxidation of $\mathrm{NADH}$ was measured photometrically at $340 \mathrm{~nm}$.

Acetoin: $\mathrm{NAD}^{+}$oxidoreductase activity was measured in $1 \mathrm{ml}$ of buffer containing $100 \mathrm{mM}$ Tris, $0.5 \mathrm{mM} \mathrm{MgCl}, 2 \mathrm{mM}$ DTE, $4 \mu \mathrm{M}$ resazurin $(\mathrm{pH}$ 7.5), and $150 \mu \mathrm{g}$ of cell extract. NAD ${ }^{+}$, TPP, and CoA were added to concentrations of $2 \mathrm{mM}, 0.8 \mathrm{mM}$, and $130 \mu \mathrm{M}$, respectively. The reaction was started by the addition of $10 \mathrm{mM}$ acetoin. The formation of NADH was measured photometrically at $340 \mathrm{~nm}$.

Acetoin:DCPIP oxidoreductase activity was measured in $1 \mathrm{ml}$ of buffer containing $100 \mathrm{mM}$ Tris, $0.5 \mathrm{mM} \mathrm{MgCl}, 2 \mathrm{mM}$ DTE, and $4 \mu \mathrm{M}$ resazurin
A

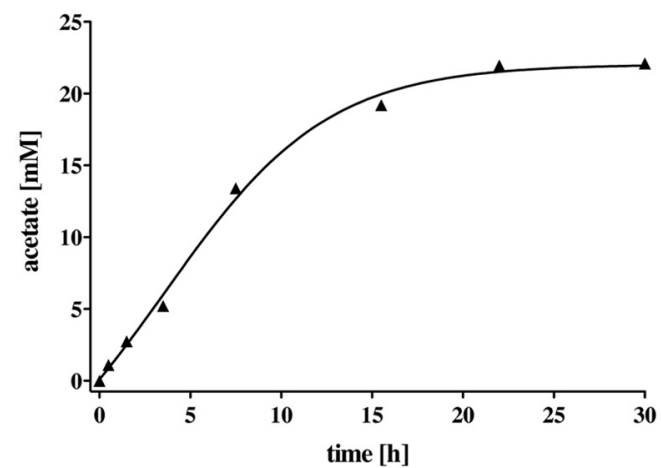

B

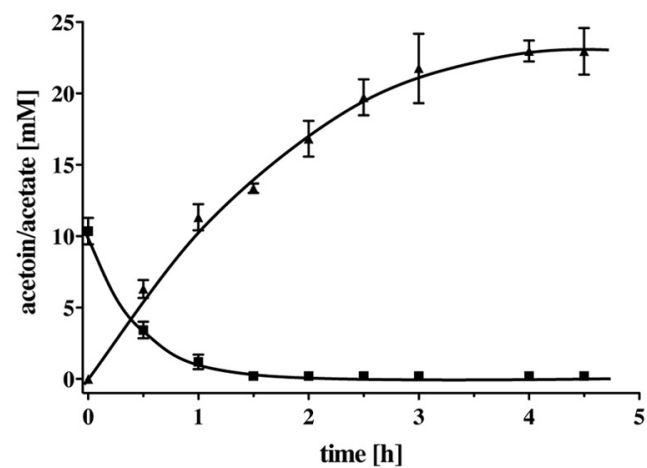

FIG 2 Acetate formation from 2,3-BD (A) and acetoin (B) by resting cells of A. woodii. A. woodii was grown on 2,3-BD, and resting cells were prepared. The reaction was started by the addition of either 2,3-BD (A) or acetoin (B) to a final concentration of $10 \mathrm{mM}$ each. Concentrations of acetoin ( $\mathbf{\square})$ and acetate ( $\mathbf{\Delta})$ were determined by gas chromatography. The data shown are representative for three independent experiments (A), or the values are means from four replicates (B). 
( $\mathrm{pH}$ 7.5). TPP and DCPIP were added to concentrations of $0.8 \mathrm{mM}$ and $150 \mu \mathrm{M}$, respectively, cell extract was added to a concentration of 150 $\mu \mathrm{g} / \mathrm{ml}$. The reaction was started by the addition of $10 \mathrm{mM}$ acetoin. Reduction of DCPIP was measured photometrically at $604 \mathrm{~nm}$.

$\mathrm{NADH}$ :lipoamide oxidoreductase activity was measured in $1 \mathrm{ml}$ of buffer containing $100 \mathrm{mM}$ Tris, $0.5 \mathrm{mM} \mathrm{MgCl}_{2}, 2 \mathrm{mM} \mathrm{DTE}, 4 \mu \mathrm{M}$ resazurin ( $\mathrm{pH} 7.5)$, and $150 \mu \mathrm{g}$ of cell extract. NADH was added to a concentration of $200 \mu \mathrm{M}$. The reaction was started by addition of $2 \mathrm{mM}$ lipoamide. Oxidation of NADH was measured photometrically at $340 \mathrm{~nm}$.

Acetaldehyde: $\mathrm{NAD}^{+}$oxidoreductase activity was measured in $1 \mathrm{ml}$ of buffer containing $35 \mathrm{mM} \mathrm{KP}$ ( $\mathrm{pH} 8$ ), $2 \mathrm{mM} \mathrm{DTE}$, and $4 \mu \mathrm{M}$ resazurin. $\mathrm{NAD}^{+}$, cell extract, and acetaldehyde were added to concentrations of 1.8 $\mathrm{mM}, 150 \mu \mathrm{g} / \mathrm{ml}$, and $10 \mathrm{mM}$, respectively. The reaction was started by the addition of $200 \mu \mathrm{M}$ CoA. The formation of NADH was measured photometrically at $340 \mathrm{~nm}$.

Measurement of $\mathrm{Fd}^{2-}: \mathrm{NAD}^{+}$oxidoreductase (Rnf) activity at membranes was performed as described previously (27).

Analytical methods. Protein concentrations were measured according to the method of Bradford (28).

Calculations. Curve fitting and determination of the kinetic parameters $K_{m}$ (Michaelis constant) and $V_{\max }$ (maximal enzyme velocity) were performed with GraphPad Prism version 4.03 and the Michaelis-Menten equation $\left[Y=\left(V_{\max } \times X\right) /\left(K_{m}+X\right)\right]$ using a nonlinear fit based on least-squares analysis. The standard Gibbs free energy of a reaction $\left(\Delta G^{0 \prime}\right)$ was calculated from the standard Gibbs free energy of formation $\left(\Delta G_{\mathrm{f}}{ }^{0}\right)$ of the products and reactants $(29,30)$.

\section{RESULTS}

Growth of $A$. woodii on 2,3-butanediol and acetoin. 2,3-BD allowed growth of $A$. woodii up to a final $\mathrm{OD}_{600}$ of $0.68 \pm 0.11$ with an optimal substrate concentration of $20 \mathrm{mM}$ (Fig. 1) and a doubling time of $8.3 \mathrm{~h}$. The oxidation product of 2,3-BD, acetoin, also allowed growth of $A$. woodii as described previously for Pelobacter carbinolicus and some strains of $A$. woodii $(30,31)$. The optimal acetoin concentration was determined to be $20 \mathrm{mM}$. A final $\mathrm{OD}_{600}$ of $1.87 \pm 0.17$ was reached within $36 \mathrm{~h}$, and the doubling time was $4.6 \mathrm{~h}$ (Fig. 1). Analysis of the product pool after growth on 2,3-BD or acetoin showed that both substrates were converted exclusively to acetate. Other end products, such as ethanol, could not be detected (data not shown).

Acetate is the only end product of 2,3-BD and acetoin degradation by resting cells of $A$. woodii. To get a first insight into the pathway of 2,3-BD degradation in $A$. woodii, we analyzed the product pool in cell suspensions oxidizing 2,3-BD. As evident from Fig. 2A, $10 \mathrm{mM}$ 2,3-BD was converted to $22 \mathrm{mM}$ acetate within $30 \mathrm{~h}$ with an initial rate of $1.6 \mu \mathrm{mol}$ of acetate $\mathrm{mg}^{-1} \mathrm{~h}^{-1}$. The formation of ethanol could not be detected. A quantification of 2,3-BD was not possible due to the presence of several stereoisomers with unknown identity. Therefore, we performed a stoichiometric analysis for the conversion of acetoin. As evident from Fig. 2B, resting cells of $A$. woodii grown on 2,3-BD degraded 10 $\mathrm{mM}$ acetoin within $90 \mathrm{~min}$. Again, only acetate could be detected as final end product with a concentration of $23 \pm 2 \mathrm{mM}$. One mole of acetoin was converted to $2.3 \mathrm{~mol}$ of acetate. Since the ratio exceeds 1:2, additional acetate must have been produced via a second pathway. Interestingly, as seen before with cells grown on 1,2-PD (24), acetoin consumption was faster than acetate production: $10 \mathrm{mM}$ acetoin was consumed completely within $90 \mathrm{~min}$ with an initial rate of $14 \mu \mathrm{mol}$ of acetoin $\mathrm{mg}^{-1} \mathrm{~h}^{-1}$, whereas 23 $\mathrm{mM}$ acetate was produced only after $4 \mathrm{~h}$ with an initial rate of 11 $\mu \mathrm{mol}$ of acetate $\mathrm{mg}^{-1} \mathrm{~h}^{-1}$. Based on equation 1 (see below), the carbon recovery from acetoin was calculated to be $89 \%$.
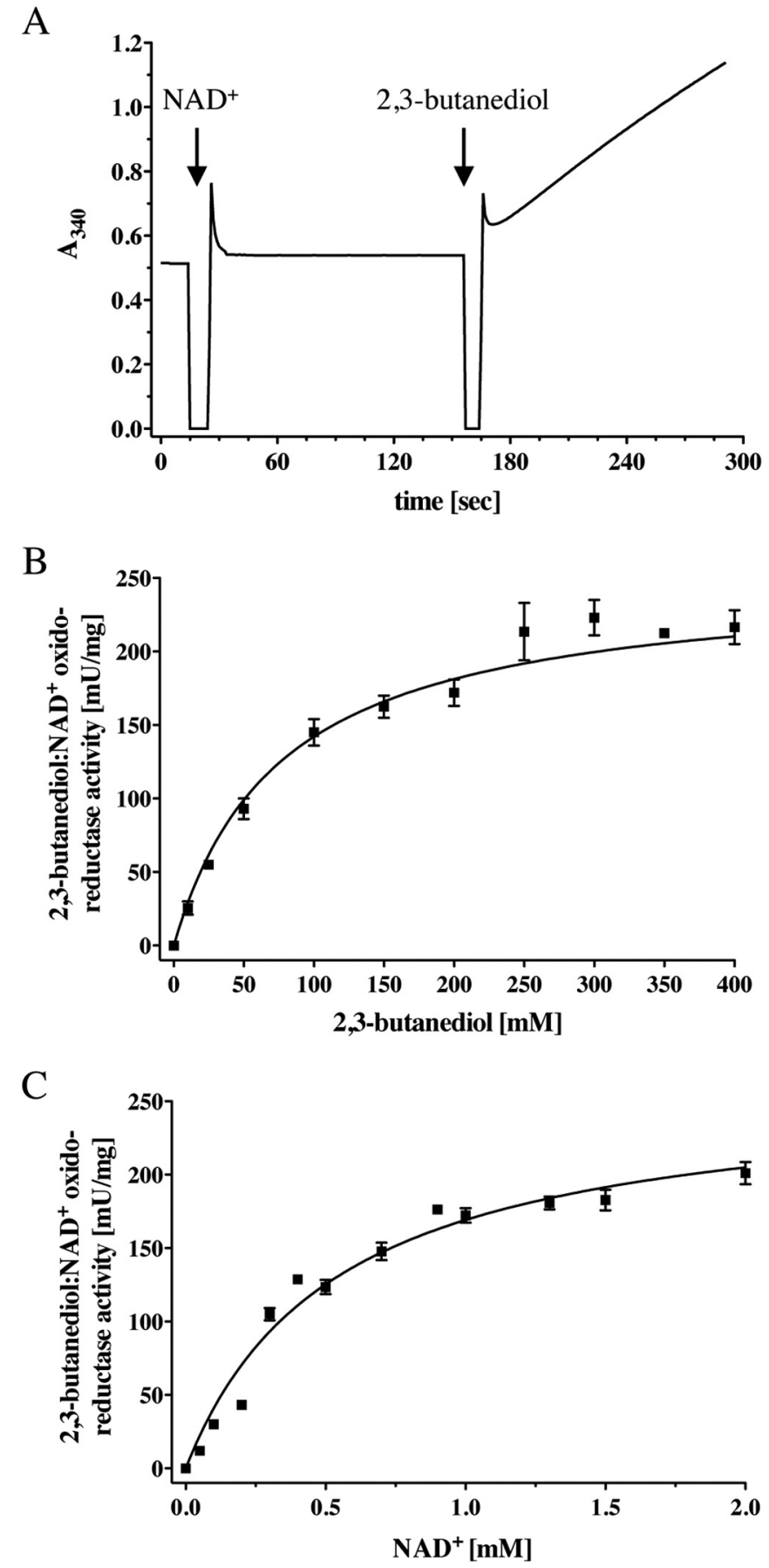

FIG 3 Enzymatic characterization of the 2,3-BD:NAD ${ }^{+}$oxidoreductase activity in cell extract of $A$. woodii grown on 2,3-BD. Electron transfer from 2,3-BD to $\mathrm{NAD}^{+}$in cell extract of $A$. woodii was measured at $30^{\circ} \mathrm{C}$ anaerobically under an $\mathrm{N}_{2}$ atmosphere in buffer containing $200 \mathrm{mM}$ glycine ( $\mathrm{pH}$ 9), $4 \mu \mathrm{M}$ resazurin, and $2 \mathrm{mM}$ DTE. 2,3-BD and $\mathrm{NAD}^{+}$were added to concentrations of 300 and $1 \mathrm{mM}$, respectively (A). Michaelis-Menten kinetics for 2,3-BD (B) and $\mathrm{NAD}^{+}(\mathrm{C})$ are shown. All values are means from three replicates.

Characterization of an $\mathrm{NAD}^{+}$-dependent 2,3-BD dehydrogenase. In order to unravel the enzymatic reactions mediating the conversion of 2,3-BD to acetate, the enzymatic activities were determined. Cell extract of $A$. woodii grown on 2,3-BD catalyzed the 


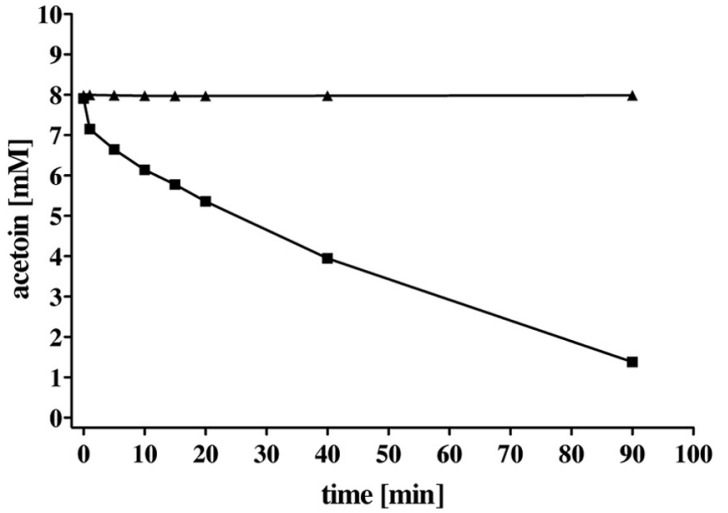

FIG $4 \mathrm{NAD}^{+}$-dependent decrease of acetoin in cell extract of 2,3-BD-grown cells. The assay was performed anaerobically $\left(\mathrm{N}_{2}\right.$ atmosphere) in buffer (100 $\mathrm{mM}$ Tris- $\mathrm{HCl}, 0.5 \mathrm{mM} \mathrm{MgCl} 2,2 \mathrm{mM}$ DTE, $4 \mu \mathrm{M}$ resazurin; $\mathrm{pH}$ 7.5) containing $8 \mathrm{mM}$ acetoin, $100 \mu \mathrm{M} \mathrm{CoA}$, and $0.8 \mathrm{mM}$ TPP. At time point zero, $\mathrm{NAD}^{+}$ was added to a final concentration of $10 \mathrm{mM}(\mathbf{\square})$, or water was added as a control $(\mathbf{\Lambda})$. The decrease in acetoin was measured by gas chromatography. The curves shown are representative for three experiments using independent preparations of cell extract.

endergonic electron transfer from 2,3-BD to $\operatorname{NAD}^{+}\left(\Delta G^{0 \prime}=\right.$ $+23.96 \mathrm{~kJ} / \mathrm{mol}$ ) (Fig. 3A). This activity was not observed in fructose-grown cells. Electron transfer was strictly dependent on the addition of both substrates and followed Michaelis-Menten kinetics (Fig. 3B and C). The $K_{m}$ value for $\mathrm{NAD}^{+}$was determined to be $413 \pm 3 \mu \mathrm{M}$, the $K_{m}$ value for the substrate 2,3-BD was comparatively high $(99 \pm 14 \mathrm{mM})$, and the $V_{\max }$ was $222 \pm 7 \mathrm{mU} / \mathrm{mg}$. The optimal $\mathrm{pH}$ for $\mathrm{NAD}^{+}$reduction was 9 . The cell extract not only oxidized 2,3-BD but also 1,3-BD, 1,2-BD, and 1,2-PD with 24, 30, and $73 \%$, respectively, of the activity obtained with 2,3-BD (data not shown). Ethanol was not used as electron donor for $\mathrm{NAD}^{+}$ reduction under the conditions tested. Cell extract also catalyzed the reverse reaction, reduction of acetoin with NADH as reductant. This was observed in cell extract from both, acetoin and
2,3-BD-grown cells with specific activities of $240 \pm 24 \mathrm{mU} / \mathrm{mg}$ and $170 \pm 7 \mathrm{mU} / \mathrm{mg}$, respectively.

Characterization of acetoin oxidation. Growth of cells on acetoin as well as $\mathrm{NAD}^{+}$-dependent oxidation of 2,3-BD implies acetoin as an intermediate of the pathway. Therefore, we next analyzed the fate of acetoin. However, acetoin-dependent $\mathrm{NAD}^{+}$ reduction was not observed in cell extracts of 2,3-BD-grown cells. Since this was surprising and may result from other activities reoxidizing $\mathrm{NADH}$, we did not analyze for $\mathrm{NAD}^{+}$reduction but for acetoin utilization by gas chromatography. As can be seen in Fig. 4 , acetoin disappeared from cell extract with a specific activity of $93 \pm 21 \mathrm{mU} / \mathrm{mg}$. This activity was $\mathrm{NAD}^{+}$dependent.

To further analyze the kinetic parameters of the acetoin dehydrogenase, we took advantage of the fact that this is a multisubunit enzyme complex catalyzing individual reactions (32). The E1 subunit catalyzes electron transfer from acetoin to the artificial electron carrier DCPIP $(32,33)$ and indeed this activity was catalyzed by cell extract of 2,3-BD-grown cells of $A$. woodii (Fig. 5A). The specific activity was determined to be $423 \pm 3 \mathrm{mU} / \mathrm{mg}$. A similar value $(470 \pm 10 \mathrm{mU} / \mathrm{mg})$ was obtained for the same reaction in cell extract from cells grown on acetoin. Furthermore, the activity of subunit E3 of the acetoin dehydrogenase could also be measured in cell extract from 2,3-BD-grown cells (Fig. 5B), albeit the rate of the reaction was slow. Electron transfer from NADH to lipoamide occurred with a specific activity of $12 \pm 1 \mathrm{mU} / \mathrm{mg}$. The same activity was also present in acetoin-grown cells with an electron transfer rate of $22 \pm 2 \mathrm{mU} / \mathrm{mg}$. None of these oxidoreductase activities was detectable in cell extracts of fructose-grown cells (data not shown). In order to characterize the kinetic parameters of $\mathrm{NAD}^{+}$-dependent oxidation of acetoin, we tested whether electron transfer from acetoin to $\mathrm{NAD}^{+}$could be measured in the cell extracts of acetoin-grown cells. Indeed, $\mathrm{NAD}^{+}$was reduced after the addition of acetoin to the assay, and the activity was strictly dependent on the presence of acetoin, CoA, and cell extract (Fig. 6A and B). The specific activity of electron transfer from acetoin to $\mathrm{NAD}^{+}$was determined to be $140 \pm 5 \mathrm{mU} / \mathrm{mg}$. The
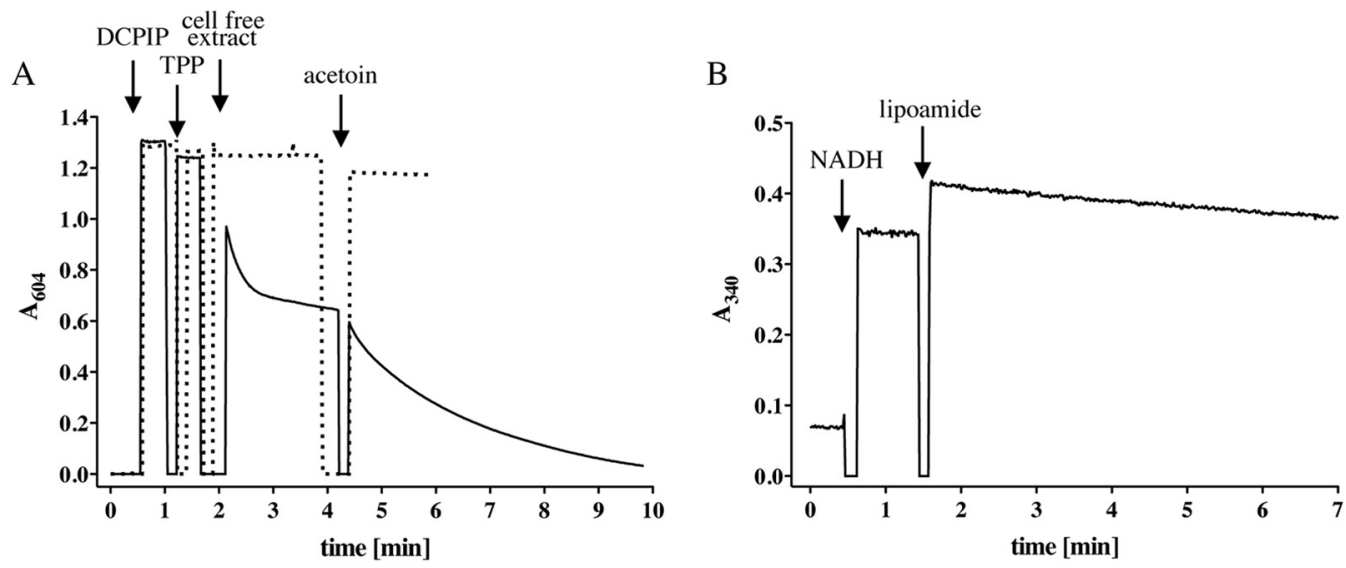

FIG 5 Enzymatic assay measuring the acetoin:DCPIP (A) or NADH:lipoamide (B) activity in cell extract of 2,3-BD-grown cells of A. woodii. Measurements were performed at $30^{\circ} \mathrm{C}$ in 1 -ml-glass cuvettes under a $\mathrm{N}_{2}$ atmosphere containing $1 \mathrm{ml}$ of buffer $\left(100 \mathrm{mM} \mathrm{Tris-} \mathrm{HCl}\right.$ [pH 7.5 ], $0.5 \mathrm{mM} \mathrm{MgCl}{ }_{2}, 4 \mu \mathrm{M} \mathrm{resazurin}$, and 2 mM DTE). (A) To measure the acetoin:DCPIP oxidoreductase activity, TPP and DCPIP were added to concentrations of 0.8 and 0.15 mM, respectively. The reaction was started by addition of $10 \mathrm{mM}$ acetoin. Reduction of DCPIP was measured at $604 \mathrm{~nm}$, either in the presence (solid line) or in the absence (dotted line) of $150 \mu \mathrm{g}$ of cell extract. (B) For measurement of NADH:lipoamide oxidoreductase activity, NADH was added to a concentration of $200 \mu \mathrm{M}$. The reaction was started by the addition of $2 \mathrm{mM}$ lipoamide. Oxidation of NADH was measured at $340 \mathrm{~nm}$. The curves shown are representative for three experiments from independent preparations of cell extract. 
A

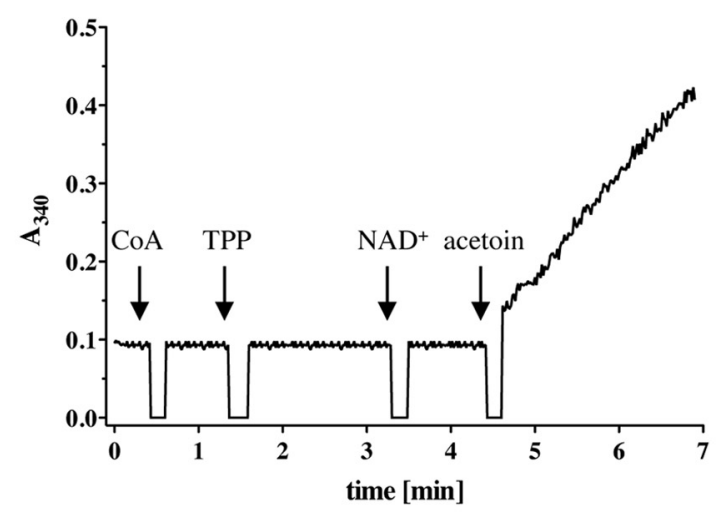

$\mathrm{C}$

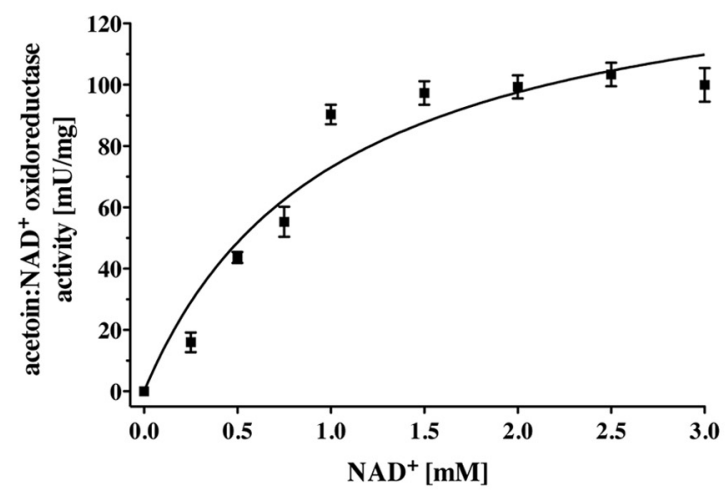

E

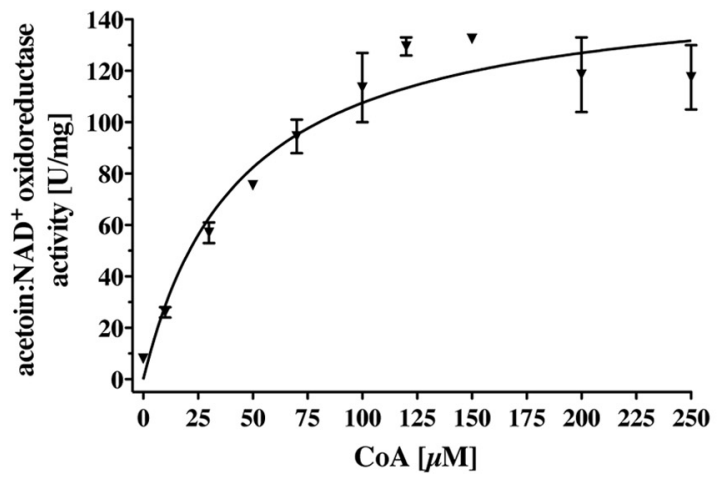

B

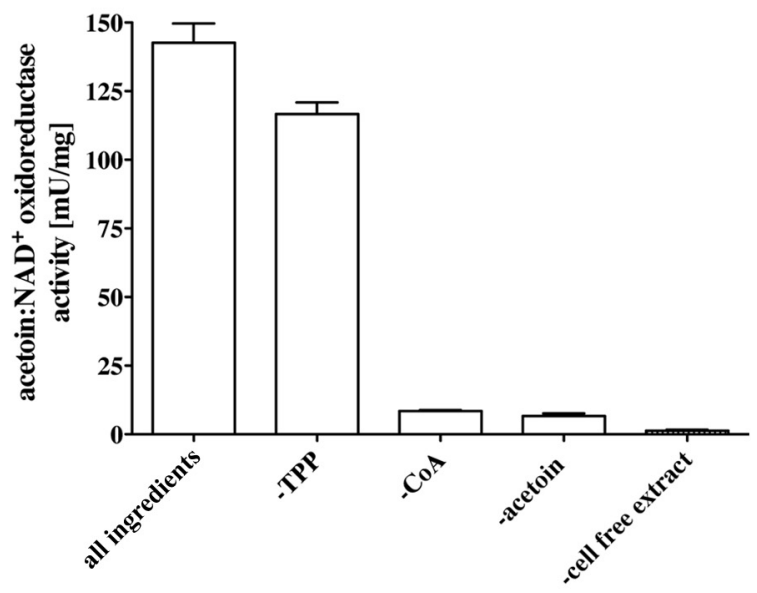

$\mathrm{D}$

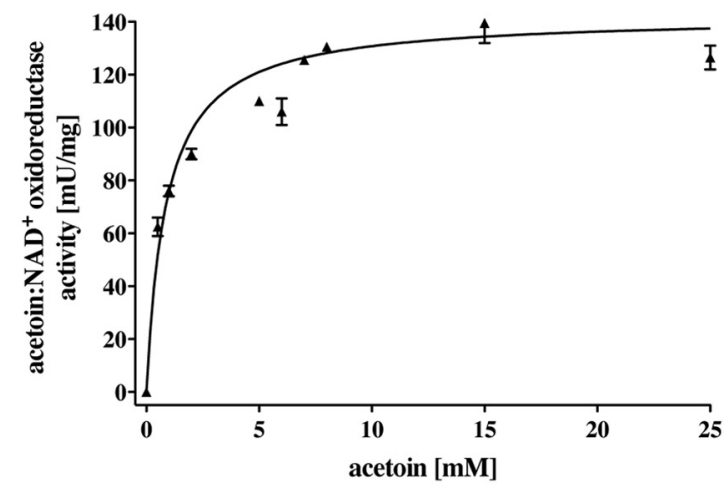

FIG 6 Enzymatic characterization of the acetoin: $\mathrm{NAD}^{+}$oxidoreductase activity in cell extract of $A$. woodii grown on acetoin. Electron transfer from acetoin to $\mathrm{NAD}^{+}$in cell extract of $A$. woodii was measured at $30^{\circ} \mathrm{C}$ anaerobically under an $\mathrm{N}_{2}$ atmosphere in buffer containing $100 \mathrm{mM} \mathrm{Tris}(\mathrm{pH} 7.5), 0.5 \mathrm{mM} \mathrm{MgCl}, 4 \mu \mathrm{M}$ resazurin, and $2 \mathrm{mM} \mathrm{DTE}$. Acetoin, $\mathrm{NAD}^{+}$, TPP, and CoA were added to concentrations of 10, 2, 0.8, and 0.13 mM, respectively (A). Michaelis-Menten kinetics for $\mathrm{NAD}^{+}(\mathrm{C})$, acetoin $(\mathrm{D})$, and $\mathrm{CoA}(\mathrm{E})$ are shown. All values are mean from three replicates.

dependence on $\mathrm{NAD}^{+}$, acetoin, and $\mathrm{CoA}$, followed MichaelisMenten kinetics (Fig. 6C to E) and the apparent $K_{m}$ values were determined to be $1 \pm 0.3 \mathrm{mM}$ for $\mathrm{NAD}^{+}, 0.9 \pm 0.17 \mathrm{mM}$ for acetoin, and $44 \pm 8 \mu \mathrm{M}$ for CoA.

Conversion of acetaldehyde to acetyl-CoA by cell extract of cells grown on 2,3-BD. The experiments described thus far are consistent with an oxidative cleavage of acetoin to acetyl-CoA and acetaldehyde. To analyze the fate of acetaldehyde, we searched for acetaldehyde dehydrogenase activity. Indeed, the cell extract of 2,3-BD-grown cells catalyzed the exergonic acetaldehyde-dependent reduction of $\operatorname{NAD}^{+}\left(\Delta G^{0 \prime}=-17.5 \mathrm{~kJ} / \mathrm{mol}\right.$ [29]) (Fig. 7) with a specific activity of $284 \pm 12 \mathrm{mU} / \mathrm{mg}$. This activity was not observed in fructose-grown cells and the reaction was strictly $\mathrm{CoA}$ dependent (Fig. 7), indicating acetyl-CoA as product of the reaction.

In sum, the data are consistent with the oxidation of 2,3-BD to 


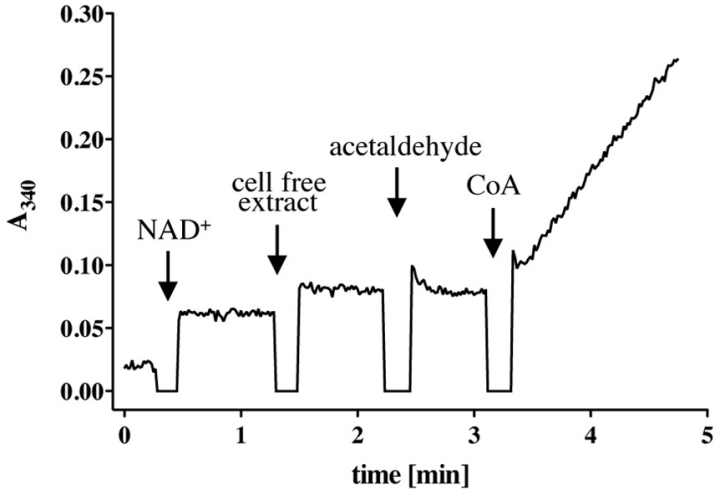

FIG 7 CoA- and acetaldehyde-dependent reduction of $\mathrm{NAD}^{+}$in cell extract of 2,3-BD-grown cells. Electron transfer from acetaldehyde to $\mathrm{NAD}^{+}$was measured at $30^{\circ} \mathrm{C}$ under $\mathrm{N}_{2}$ atmosphere in $1 \mathrm{ml}$ of $\mathrm{KP}_{\mathrm{i}}$ buffer $(35 \mathrm{mM} \mathrm{KP}, 2$ mM DTE, $4 \mu \mathrm{M}$ resazurin; $\mathrm{pH}$ 8) containing $150 \mu \mathrm{g}$ of cell extract, $1.8 \mathrm{mM}$ $\mathrm{NAD}^{+}$, and $10 \mathrm{mM}$ acetaldehyde. The reaction was started by the addition of $200 \mu \mathrm{M} \mathrm{CoA}$. The formation of NADH was measured photometrically at 340 $\mathrm{nm}$. The curve shown is representative for three experiments.

$2 \mathrm{~mol}$ of acetyl-CoA and the concomitant reduction of $3 \mathrm{~mol}$ of $\mathrm{NAD}^{+}$. Since all of the acetyl-CoA is converted to acetate, the question arose how NADH is reoxidized. For $A$. woodii as an acetogenic bacterium, $\mathrm{CO}_{2}$ is the obvious electron acceptor. The involvement of the WLP in 2,3-BD conversion was tested next with cell suspensions.

Acetate formation from 2,3-BD is $\mathrm{Na}^{+}$and $\mathrm{CO}_{2}$ dependent. In the presence of $\mathrm{CO}_{2}$, bicarbonate, and $\mathrm{NaCl}$, resting cells of $A$. woodii converted $10 \mathrm{mM} 2,3-\mathrm{BD}$ to $22 \mathrm{mM}$ acetate within $30 \mathrm{~h}$ (Fig. 8). Acetate formation was strictly dependent on $\mathrm{CO}_{2} /$ carbonate. If no additional $\mathrm{Na}^{+}$was added or in the presence of a sodium ionophore, acetate formation from 2,3-BD was largely inhibited. A similar pattern of acetate formation was observed when acetoin was the substrate (data not shown). The dependence of acetate formation on $\mathrm{Na}^{+}$or a transmembrane $\mathrm{Na}^{+}$gradient, as evident from the inhibition of acetate formation by a sodium ionophore, also indicates the involvement of the WLP in 2,3-BD metabolism.

In order to further prove the involvement of the WLP in 2,3-BD degradation, we measured the enzymatic activity of the coupling site of the WLP, the Rnf complex. Indeed, electron flow from reduced ferredoxin to $\mathrm{NAD}^{+}$at membranes of 2,3-BDgrown cells of $A$. woodii occurred with a rate of $53 \pm 3 \mathrm{mU} / \mathrm{mg}$. This is in the same range as measured before for fructose-grown cells (50 $\pm 5 \mathrm{mU} / \mathrm{mg}$ [27]).

\section{DISCUSSION}

Acetogenic bacteria are able to grow chemolithoautotrophically with $\mathrm{H}_{2}$ as an electron source and $\mathrm{CO}_{2}$ as a carbon source, thereby forming acetate as the end product (6). Furthermore, they are also able to grow chemoorganoheterotrophically on sugars, acids, or alcohols (17). The oxidation of these organic substrates leads to the formation of reducing equivalents, which are usually disposed of in the WLP, resulting in the reduction of $\mathrm{CO}_{2}$ to acetate. Only recently, we found that growth of the model acetogen $A$. woodii on the diol 1,2-PD is nonacetogenic, since the substrate is disproportionated into propanol and propionate (24). In the present study, we show that degradation of the diol 2,3-BD by $A$. woodii is not independent of acetogenesis but that oxidation of 2,3-BD is coupled to the reduction of $\mathrm{CO}_{2}$ via the WLP.

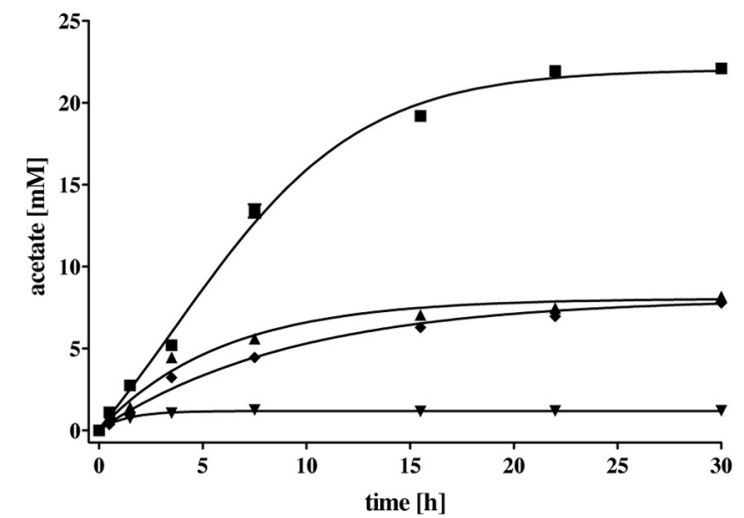

FIG 8 Acetate formation from 2,3-BD by resting cells of $A$. woodii is $\mathrm{CO}_{2}$ and $\mathrm{Na}^{+}$dependent. Whole cells of $A$. woodii were incubated with $10 \mathrm{mM}$ 2,3-BD in buffer containing $50 \mathrm{mM}$ imidazole, $20 \mathrm{mM} \mathrm{KCl,} 5 \mathrm{mM} \mathrm{MgSO}_{4}, 2 \mathrm{mM} \mathrm{DTE}$, and $4 \mu \mathrm{M}$ resazurin ( $\mathrm{pH} 7$ ). Supplements and the gaseous atmosphere were as indicated. Symbols: $\mathbf{\square}, 20 \mathrm{mM} \mathrm{NaCl}, 20 \mathrm{mM} \mathrm{KHCO}_{3}, \mathrm{~N}_{2} / \mathrm{CO}_{2}$ atmosphere; $20 \mathrm{mM} \mathrm{NaCl}, 20 \mathrm{mM} \mathrm{KHCO}{ }_{3}, 80 \mu \mathrm{M}$ ETH2120, $\mathrm{N}_{2} / \mathrm{CO}_{2}$ atmosphere; $\boldsymbol{\Delta}, 20$ $\mathrm{mM} \mathrm{KHCO}_{3}, \mathrm{~N}_{2} / \mathrm{CO}_{2}$ atmosphere; $\boldsymbol{\nabla}, 20 \mathrm{mM} \mathrm{NaCl}, \mathrm{N}_{2}$ atmosphere. The data shown are representative for three independent experiments.

It was previously shown that $A$. woodii can grow on $2,3-\mathrm{BD}$ and acetoin, respectively; however, not all strains grew on these substrates (31). Therefore, we started by analyzing whether $A$. woodii DSM 1030 can grow on 2,3-BD and acetoin. Indeed, this was the case and $A$. woodii only produced acetate as end product, ethanol could not be detected. It was striking that the final $\mathrm{OD}_{600}$ when growing on acetoin was $150 \%$ higher than growth on $2,3-\mathrm{BD}$, and also the doubling time on acetoin was only half as long as with 2,3-BD. The higher optical density might indicate a higher ATP yield from acetoin as carbon and energy source compared to 2,3BD. According to equation 1, the metabolism of acetoin by $A$. woodii might allow the phosphorylation of $1.55 \mathrm{~mol}$ ADP per mol of acetoin, whereas the degradation of 1 mol 2,3-BD (equation 2) only allows the phosphorylation of $1.3 \mathrm{~mol}$ ADP per mol of 2,3-BD (see Fig. 10):

$$
\text { Acetoin }+\mathrm{CO}_{2}+\mathrm{H}_{2} \mathrm{O} \rightarrow 2.5 \text { acetate }+2.5 \mathrm{H}^{+}
$$

where $\Delta G^{0 \prime}=-117.1 \mathrm{~kJ} / \mathrm{mol}$, and

$$
2,3-\mathrm{BD}+1.5 \mathrm{CO}_{2}+0.5 \mathrm{H}_{2} \mathrm{O} \rightarrow 2.75 \text { acetate }+2.75 \mathrm{H}^{+}
$$

where $\Delta G^{0 \prime}=-93.6 \mathrm{~kJ} / \mathrm{mol}$.

The increased doubling time on acetoin might be due to a low affinity of the butanediol-oxidizing enzyme for its substrate. Indeed, a following enzymatic characterization of the 2,3-BD dehydrogenase of $A$. woodii showed a high $K_{m}$ of $99 \mathrm{mM} 2,3-\mathrm{BD}$ and $V_{\max }$ was only achieved in the presence of $300 \mathrm{mM} 2,3-\mathrm{BD}$. The $K_{m}$ of the acetoin dehydrogenase for acetoin was determined to be only $1 \mathrm{mM}$, giving a reason for the faster growth of $A$. woodii on this substrate. Of course, this calculation does not include the intracellular substrate concentration due to active import of 2,3-BD and acetoin, but a 2,3-BD concentration of $300 \mathrm{mM}$ in $A$. woodii is very unlikely. A similar observation was seen with cell suspensions: again, only acetate was the end product on either 10 $\mathrm{mM}$ 2,3-BD or $10 \mathrm{mM}$ acetoin and, again, acetate production from acetoin was 5 times faster than from 2,3-BD. This supports the hypothesis made above that the low affinity of the butanediol dehydrogenase for the diol is the bottleneck in 2,3-BD conversion. 


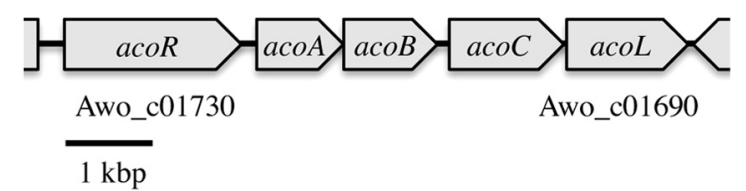

FIG 9 Genetic organization of the aco gene cluster of A. woodii. acoR is annotated as a putative transcriptional activator, $a c o A$ and $a c o B$ encode the subunits $\alpha$ and $\beta$, respectively, of subunit E1 (TPP-dependent acetoin dehydrogenase), $a c o C$ encodes subunit E2 (dihydrolipoamide acetyltransferase), and acoL codes for subunit E3 (dihydrolipoamide dehydrogenase) of the acetoin dehydrogenase complex.

Another interesting observation was the slow formation of acetate compared to the rate of acetoin consumption. This was seen before for the conversion of 1,2-PD and might indicate that an intermediate of the pathway is stored within the cells. Since the formation of bacterial microcompartments in A. woodii on 2,3BD-grown cells was already shown (24), the assumption is likely that the toxic product of the acetoin dehydrogenase reaction, acetaldehyde, is stored within those compartments and that it is only slowly further converted to acetate.

In this study we could show that in A. woodii, 2,3-BD is first oxidized to acetoin in an $\mathrm{NAD}^{+}$-dependent reaction and then further oxidized to acetyl-CoA and acetaldehyde. The first reaction is mediated by an alcohol dehydrogenase, which we could characterize here, but an assignment of this enzyme to 1 of the 11 alcohol dehydrogenases encoded in the genome of $A$. woodii (34) is not possible. However, the situation was different for the second step of this metabolism: the oxidative cleavage of acetoin. In $P$. carbinolicus, acetoin is known to be oxidized $\mathrm{NAD}^{+}$and $\mathrm{CoA}$ dependent by a heterotetrameric enzyme complex, giving the end products acetyl-CoA and acetaldehyde $(32,35)$. Indeed, the genome of A. woodii revealed two gene clusters (Awoc_01720-01690 and Awoc_29430-29400) that encode all subunits of a putative acetoin dehydrogenase (36). The first of the two clusters is preceded by a gene annotated as putative transcriptional activator (acoR/Awoc_01730, Fig. 9). Since the oxidation of $\alpha$-oxoglutarate to succinyl-CoA in the tricarboxylic acid cycle is a "housekeeping" activity and catalyzed by a highly similar complex, we would assume that the second gene cluster without the upstream regulator codes for an $\alpha$-ketoglutarate dehydrogenase. The genes aco $A$ and acoB encode the subunits $\alpha$ and $\beta$, respectively, of the subunit E1 of the acetoin dehydrogenase, catalyzing the oxidation of acetoin. $a c o B$ codes for the subunit E2, a dihydrolipoamide dehydrogenase and $a c o L$ encodes subunit E3, catalyzing electron transfer from dihydrolipoamide to $\mathrm{NAD}^{+}(32)$.

Based on the data gained in the present study, the following pathway of 2,3-BD oxidation is proposed. 2,3-BD is initially oxidized to acetoin in an $\mathrm{NAD}^{+}$-dependent reaction. Subsequently, acetoin is further oxidized in a second $\mathrm{NAD}^{+}$-dependent reaction. Since this reaction is also dependent on the presence of CoA, we presume that the oxidation of acetoin is catalyzed by an acetoin dehydrogenase, resulting in acetyl-CoA and acetaldehyde as intermediates. Product analysis in growing and resting cells by gas chromatography showed that the only end product of 2,3-BD metabolism is acetate, indicating that both acetyl-CoA and acetaldehyde are converted to this product. Acetyl-CoA is converted by the enzymes phosphotransacetylase and acetate kinase, two enzymes whose encoding genes are known to be present in A. woodii (34). The presence of a CoA-dependent acetaldehyde dehydrogenase was supported by the measurement of an $\mathrm{NAD}^{+}$- and CoA-dependent oxidation of acetaldehyde in cell extract of 2,3-BD-grown cells. The stoichiometries obtained by measuring the substrate and product pool in the present study, as well the carbonate and $\mathrm{Na}^{+}$dependence of acetate formation from both 2,3-BD and acetoin, indicate that NADH produced from the stepwise oxidation of 2,3-BD is shuttled into the WLP to produce another acetate via the reduction of $\mathrm{CO}_{2}$ (equation 2). A model for the conversion of 2,3-BD by $A$. woodii is shown in Fig. 10. In order to provide molecular hydrogen and reduced ferredoxin for the initial reduction of the two molecules $\mathrm{CO}_{2}$ in the WLP, the membrane-bound Rnf complex has to reduce ferredoxin with electrons coming from $\mathrm{NADH}$, using a transmembrane $\mathrm{Na}^{+}$gradient as driving force for this endergonic reduction. This activity is the basis for the observed dependence on $\mathrm{Na}^{+}$and a transmembrane $\mathrm{Na}^{+}$gradient. Interestingly, apart from lactate metabolism (37), 2,3-BD is the

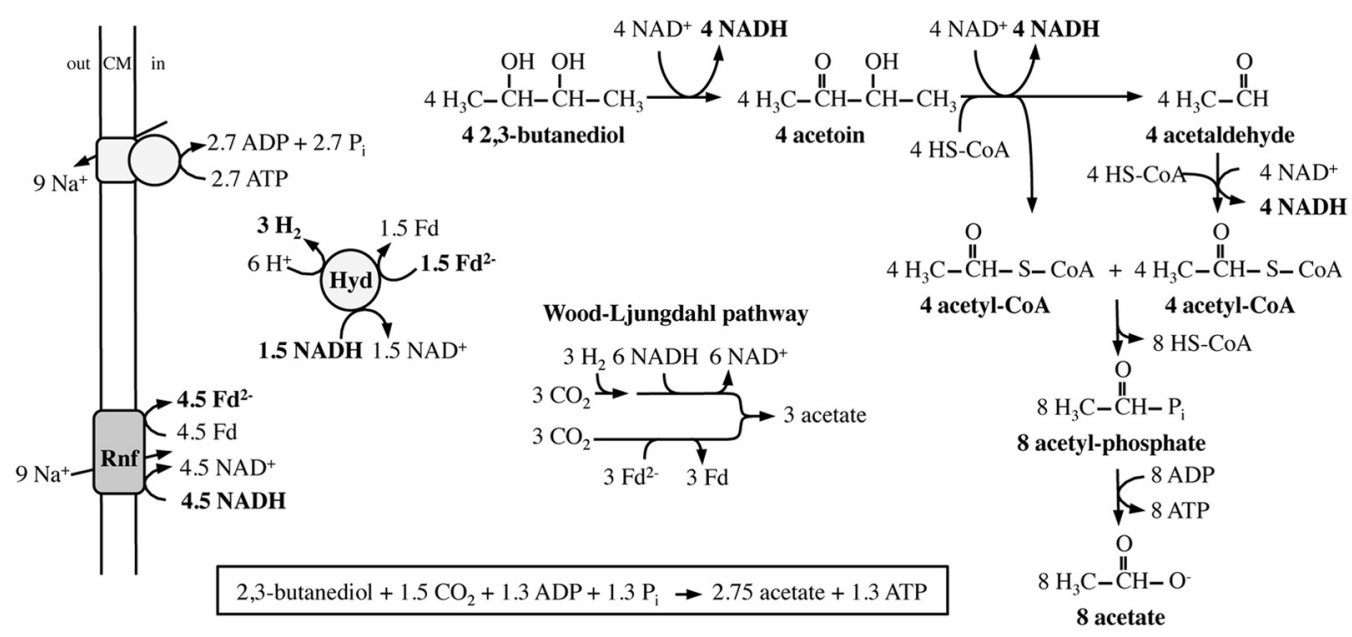

FIG 10 Model of 2,3-BD metabolism in A. woodii. 2,3-BD is initially oxidized to acetoin in an $\mathrm{NAD}^{+}$-dependent reaction. Acetoin is further converted to acetyl-CoA and acetaldehyde, producing another NADH. Both intermediates are converted to acetate, thereby conserving energy via substrate level phosphorylation in the acetate kinase reaction. Reducing equivalents formed during oxidation of 2,3-BD are channeled into the Wood-Ljungdahl pathway. $\mathrm{Fd}^{2-}$, reduced ferredoxin. 
second known substrate that requires reverse electron transport catalyzed by $\mathrm{Rnf}$ to drive ferredoxin reduction. The $\mathrm{Na}^{+}$gradient required to drive reverse electron flow is established by the $\mathrm{F}_{1} \mathrm{~F}_{\mathrm{o}}$ ATP synthase from ATP hydrolysis (38). Molecular hydrogen for reduction of $\mathrm{CO}_{2}$ to formate is provided from both reduced ferredoxin and $\mathrm{NADH}$ by an electron bifurcating hydrogenase (HydABCD) (11). Energy is conserved only by the activity of the acetate kinase via substrate level phosphorylation. Apart from lactate and 1,2-PD metabolism, this is the third pathway described in A. woodii that only relies on substrate level phosphorylation for ATP synthesis. In sum, the oxidation of 2,3-BD results in the production of $2.75 \mathrm{~mol}$ of acetate and $1.3 \mathrm{~mol}$ of ATP from $1 \mathrm{~mol}$ of 2,3-BD and $1.5 \mathrm{~mol}$ of $\mathrm{CO}_{2}$ (Fig. 10). When growing on acetoin as the sole carbon and energy source, less NADH is produced, since the initial $\mathrm{NAD}^{+}$-dependent oxidation of 2,3-BD is omitted, and the resulting stoichiometries differ slightly: $1 \mathrm{~mol}$ of acetoin and $\mathrm{CO}_{2}$ is converted to $2.5 \mathrm{~mol}$ of acetate (equation 1), resulting in the phosphorylation of $1.55 \mathrm{~mol}$ of ADP. This stoichiometry correlates with the values determined experimentally in this study (the acetoin/acetate ratio was determined to be 1:2.3 in cell suspensions), and the higher theoretical ATP yield from acetoin compared to 2,3-BD might be a reason for the higher ODs obtained for acetoin-grown cells.

\section{ACKNOWLEDGMENT}

This study was supported by a grant from the Deutsche Forschungsgemeinschaft.

\section{REFERENCES}

1. Drake HL. 1994. Acetogenesis, acetogenic bacteria, and the acetyl-CoA pathway: past and current perspectives, p 3-60. In Drake HL (ed), Acetogenesis. Chapman and Hall, New York, NY.

2. Müller V. 2003. Energy conservation in acetogenic bacteria. Appl Environ Microbiol 69:6345-6353. http://dx.doi.org/10.1128/AEM.69.11.6345-63 53.2003.

3. Ragsdale SW, Pierce E. 2008. Acetogenesis and the Wood-Ljungdahl pathway of $\mathrm{CO}_{2}$ fixation. Biochim Biophys Acta 1784:1873-1898. http: //dx.doi.org/10.1016/j.bbapap.2008.08.012.

4. Hugenholtz J, Ljungdahl LG. 1989. Electron transport and electrochemical proton gradient in membrane vesicles of Clostridium thermoaceticum. J Bacteriol 171:2873-2875.

5. Heise R, Müller V, Gottschalk G. 1993. Acetogenesis and ATP synthesis in Acetobacterium woodii are coupled via a transmembrane primary sodium ion gradient. FEMS Microbiol Lett 112:261-268. http://dx.doi.org /10.1111/j.1574-6968.1993.tb06460.x.

6. Ljungdahl LG. 1994. The acetyl-CoA pathway and the chemiosmotic generation of ATP during acetogenesis, p 63-87. In Drake HL (ed), Acetogenesis. Chapman \& Hall, New York, NY.

7. Schuchmann K, Müller V. 2014. Autotrophy at the thermodynamic limit of life: a model for energy conservation in acetogenic bacteria. Nat Rev Microbiol 12:809-821. http://dx.doi.org/10.1038/nrmicro3365.

8. Heise R, Müller V, Gottschalk G. 1989. Sodium dependence of acetate formation by the acetogenic bacterium Acetobacterium woodii. J Bacteriol 171:5473-5478.

9. Biegel E, Müller V. 2010. Bacterial $\mathrm{Na}^{+}$-translocating ferredoxin: $\mathrm{NAD}^{+}$ oxidoreductase. Proc Natl Acad Sci U S A 107:18138-18142. http://dx.doi .org/10.1073/pnas.1010318107.

10. Biegel E, Schmidt S, González JM, Müller V. 2011. Biochemistry, evolution and physiological function of the Rnf complex, a novel ion-motive electron transport complex in prokaryotes. Cell Mol Life Sci 68:613-634. http://dx.doi.org/10.1007/s00018-010-0555-8.

11. Schuchmann K, Müller V. 2012. A bacterial electron bifurcating hydrogenase. J Biol Chem 287:31165-31171. http://dx.doi.org/10.1074/jbc.M1 12.395038 .

12. Heise R, Reidlinger J, Müller V, Gottschalk G. 1991. A sodium-stimulated ATP synthase in the acetogenic bacterium Acetobacterium woodii. FEBS Lett 295:119-122. http://dx.doi.org/10.1016/0014-5793(91)81400-3.

13. Müller V, Aufurth S, Rahlfs S. 2001. The $\mathrm{Na}^{+}$cycle in Acetobacterium woodii: identification and characterization of a $\mathrm{Na}^{+}$-translocating $\mathrm{F}_{1} \mathrm{~F}_{0^{-}}$ ATPase with a mixed oligomer of 8 and $16 \mathrm{kDa}$ proteolipids. Biochim Biophys Acta 1505:108-120. http://dx.doi.org/10.1016/S0005-2728(00)0 0281-4.

14. Matthies D, Zhou W, Klyszejko AL, Anselmi C, Yildiz O, Brandt K, Müller V, Faraldo-Gomez JD, Meier T. 2014. High-resolution structure and mechanism of an F/V-hybrid rotor ring in a $\mathrm{Na}^{+}$-coupled ATP synthase. Nat Commun 5:5286. http://dx.doi.org/10.1038/ncomms6286.

15. Bache R, Pfennig N. 1981. Selective isolation of Acetobacterium woodii on methoxylated aromatic acids and determination of growth yields. Arch Microbiol 130:255-261. http://dx.doi.org/10.1007/BF00459530.

16. Eichler B, Schink B. 1984. Oxidation of primary aliphatic alcohols by Acetobacterium carbinolicum sp. nov., a homoacetogenic anaerobe. Arch Microbiol 140:147-152. http://dx.doi.org/10.1007/BF00454917.

17. Drake HL, Gössner AS, Daniel SL. 2008. Old acetogens, new light. Ann N Y Acad Sci 1125:100-128. http://dx.doi.org/10.1196/annals.1419.016.

18. Dorn M, Andreesen JR, Gottschalk G. 1978. Fermentation of fumarate and L-malate by Clostridium formicoaceticum. J Bacteriol 133:26-32.

19. Matthies C, Freiberger A, Drake HL. 1993. Fumarate dissimilation and differential reductant flow by Clostridium formicoaceticum and Clostridium aceticum. Arch Microbiol 160:273-278. http://dx.doi.org/10.1007 /BF00292076.

20. Dong X, Plugge CM, Stams AJ. 1994. Anaerobic degradation of propionate by a mesophilic acetogenic bacterium in coculture and triculture with different methanogens. Appl Environ Microbiol 60:2834-2838.

21. Fröstl JM, Seifritz C, Drake HL. 1996. Effect of nitrate on the autotrophic metabolism of the acetogens Clostridium thermoautotrophicum and Clostridium thermoaceticum. J Bacteriol 178:4597-4603.

22. Seifritz C, Daniel SL, Gößner A, Drake HL. 1993. Nitrate as a preferred electron sink for the acetogen Clostridium thermoaceticum. J Bacteriol 175: 8008-8013.

23. Drake HL, Daniel S, Küsel K, Matthies C, Kuhner C, Braus-Strohmeyer S. 1997. Acetogenic bacteria: what are the in situ consequences of their diverse metabolic diversities? Biofactors 1:13-24.

24. Schuchmann K, Schmidt S, Martinez Lopez A, Kaberline C, Kuhns M, Lorenzen W, Bode HB, Joos F, Müller V. 2015. Nonacetogenic growth of the acetogen Acetobacterium woodii on 1,2-propanediol. J Bacteriol 197: 382-391. http://dx.doi.org/10.1128/JB.02383-14.

25. Heise R, Müller V, Gottschalk G. 1992. Presence of a sodiumtranslocating ATPase in membrane vesicles of the homoacetogenic bacterium Acetobacterium woodii. Eur J Biochem 206:553-557. http://dx.doi .org/10.1111/j.1432-1033.1992.tb16959.x.

26. Schmidt K, Liaaen-Jensen S, Schlegel HG. 1963. Die Carotinoide der Thiorhodaceae. Arch Mikrobiol 46:117-126. http://dx.doi.org/10.1007 /BF00408204.

27. Hess V, Schuchmann K, Müller V. 2013. The ferredoxin: $\mathrm{NAD}^{+}$oxidoreductase (Rnf) from the acetogen Acetobacterium woodii requires $\mathrm{Na}^{+}$ and is reversibly coupled to the membrane potential. J Biol Chem 288: 31496-31502. http://dx.doi.org/10.1074/jbc.M113.510255.

28. Bradford MM. 1976. A rapid and sensitive method for the quantification of microgram quantities of protein utilizing the principle of protein-dyebinding. Anal Biochem 72:248-254. http://dx.doi.org/10.1016/0003 $-2697(76) 90527-3$.

29. Thauer RK, Jungermann K, Decker K. 1977. Energy conservation in chemotrophic anaerobic bacteria. Bact Rev 41:100-180.

30. Schink B. 1984. Fermentation of 2,3-butanediol by Pelobacter carbinolicus sp. nov. and Pelobacter propionicus sp. nov., and evidence for propionate formation from $\mathrm{C}_{2}$ compounds. Arch Microbiol 137:33-41. http://dx.doi .org/10.1007/BF00425804.

31. Schink B. 1984. Clostridium magnum sp. nov., a non-autotrophic homoacetogenic bacterium. Arch Microbiol 137:250-255. http://dx.doi.org /10.1007/BF00414553.

32. Oppermann FB, Schmidt B, Steinbüchel A. 1991. Purification and characterization of acetoin-2,6-dichlorophenolindophenol oxidoreductase, dihydrolipoamide dehydrogenase, and dihydrolipoamide acetyltransferase of the Pelobacter carbinolicus acetoin dehydrogenase enzyme system. J Bacteriol 173:757-767.

33. Lorenzl H, Oppermann FB, Schmidt B, Steinbüchel A. 1993. Purification and characterization of the E1 component of the Clostridium magnum acetoin dehydrogenase enzyme system. Antonie Van Leeuwenhoek 64:9-15. http://dx.doi.org/10.1007/BF00870916.

34. Poehlein A, Schmidt S, Kaster A-K, Goenrich M, Vollmers J, Thürmer A, Bertsch J, Schuchmann K, Voigt B, Hecker M, Daniel R, Thauer RK, 
Gottschalk G, Müller V. 2012. An ancient pathway combining carbon dioxide fixation with the generation and utilization of a sodium ion gradient for ATP synthesis. PLoS One 7:e33439. http://dx.doi.org/10.1371 /journal.pone.0033439.

35. Oppermann FB, Steinbüchel A, Schlegel HG. 1988. Utilization of methylacetoin by the strict anaerobe Pelobacter carbinolicus and consequences for the catabolism of acetoin. FEMS Microbiol Lett 55:47-52. http://dx .doi.org/10.1111/j.1574-6968.1988.tb02796.x.

36. Oppermann FB, Steinbüchel A. 1994. Identification and molecular char- acterization of the aco genes encoding the Pelobacter carbinolicus acetoin dehydrogenase enzyme system. J Bacteriol 176:469-485.

37. Weghoff MC, Bertsch J, Müller V. 2015. A novel mode of lactate metabolism in strictly anaerobic bacteria. Environ Microbiol 17:670-607. http: //dx.doi.org/10.1111/1462-2920.12493.

38. Reidlinger J, Müller V. 1994. Purification of ATP synthase from Acetobacterium woodii and identification as a $\mathrm{Na}^{+}$-translocating $\mathrm{F}_{1} \mathrm{~F}_{0}$-type enzyme. Eur J Biochem 223:275-283. http://dx.doi.org/10.1111/j.1432-1033 1994.tb18992.x. 